\title{
Taxes and Foreign Direct Investment (FDI) in Nigeria
}

\author{
Ofiafoh Eiya \\ University of Benin \\ Izilin Okaiwele \\ University of Benin
}

This study examines the relationship between the different forms of taxes collected and foreign direct investment in Nigeria. The study adopted the ex-post facto research design and covers a period of thirtyfour years from 1982 - 2015. Secondary data were analysed using the Autoregressive Distributed Lag (ARDL) regression technique. The study found that there is a negative and significant relationship between taxes collected in the form of National Information Development Fund and Education Tax and Foreign Direct Investment. Also, that there exists a positive and significant relationship between Value Added Tax, Companies Income Tax and Foreign Direct Investment, while Petroleum Profits Taxes and Custom and Excise Duties do not influence Foreign Direct Investments in Nigeria. Based on the findings, the study recommends that there is need for government to come up with more friendly economic policies such as tax incentives and macroeconomic adjustments that will enhance continuous increase and growth of the nation's GDP and by implication, attracts FDI into Nigeria.

\section{INTRODUCTION}

Revenue from taxes serves as one of the means by which governments fund the cost of providing the basic infrastructural facilities to the citizenry. As countries strive to achieve economic growth and development, the significant role of Foreign Direct Investment (FDI) in achieving this has been recognised by policy makers and the academia (Akinwunmi, Olotu, \& Adegbie, 2017; John, 2016).

Foreign direct investments refers to capital movements in the form of investments made to acquire lasting interest in enterprises operating outside of the economy of the investor (UNCTAD, 2007) and are viewed as the engine of economic growth as it provides the much needed capital for investment, increases competition in the host country industries, creates employment opportunities, protects environmental and social responsibility, and aids local firms to become more productive by adopting more efficient technology or by investing in human and/or physical capital (Peters \& Kiabel, 2015; Raian, 2004; OECD, 2002). These perceived benefits have encouraged developed and emerging economies to ensure that favourable conditions are put in place to attract investments from FDIs.

Attracting FDIs is harped on the environment of the host countries. Therefore, the volume and location of investment that comes into a country is based on the factors in place to ease their business operations, since, higher tax rates reduce after-tax returns, thereby reducing incentives to commit investment funds (Gordon \& Hines, 2002). Amongst these factors are tax exempts, cheap labour, geographical benefits, and infrastructural facilities (Akinwunmi et al., 2017; Okoi \& Edame, 2013).

16 Journal of Applied Business and Economics Vol. 21(3) 2019 
In Nigeria, with the dwindling revenue base in recent times, foreign capital from FDIs is much needed to aid the government in achieving its developmental goals. The Nigerian government in recognition of the importance of FDI as an important medium for industrial progress has readily entered into bilateral agreement with foreign governments, or private organisations that wish to invest in the country as well as discuss the additional incentives (Morisset, 2003).

The impact of tax on FDI have been acknowledged by prior studies (Akinwunmi et al., 2017; KersanSkabic \& Mirkovic, 2015; Nistor \& Paun, 2013), noting that the attractiveness of a country to foreign investors is higher when it has low and well-harnessed tax policies in place to stimulate the inflow of FDIs. However, the inflow of FDIs may be stalled by the existence of multiple taxes, complex tax rates, unfriendly environment, poor regulations and the fact that the revenue collected from taxes may not have been used to provide the needed infrastructural facilities (Gondor \& Nistor, 2012). Further, Becker, Fuest, and Hemmelgarn, (2006) observe that taxation may affect FDI in two ways. On one hand, it can reduce the average income of an investment project, influencing the decisions of internationalisation and localisation of companies; and on the other hand, it can change the cost of the companies' capital, influencing the investment decision.

Consequently, the argument in literature is that the tax policy in place encourages FDIs. Hence, the objective of this paper is to examine the relationship between taxes and FDIs in Nigeria. While prior studies examined the influence of taxes on foreign direct investment, none of these studies employed the Autoregressive Distributed Lag regression approach (ARDL) which is a dynamic model that offers better results compared to static linear models such as the Ordinary Least Square technique (OLS) as recent developments in econometrics reveal that times series studies are usually not stationary as earlier assumed. Therefore, due to the paucity of times series studies examining taxes and FDI, this study contributes to literature through the application of the autoregressive distributed lag regression approach (ARDL) to examine the short - run and long- run effect of taxes on foreign direct investment.

The remaining part of the paper is organised as follows. Section 2 provides the literature review and underpinning theory. Section 3 presents the review of prior of empirical studies. Section 4 focuses on the methodology and discussion of findings. Section 5 examines the conclusion and recommendations for further studies.

\section{LITERATURE REVIEW}

\section{Foreign Direct Investment}

Foreign direct investment refers to an investment in the form of either establishing a business or acquiring business assets by an individual or a company in a country other than the country of origin of the investor (John, 2016). Investments from foreign sources are mostly sourced by transition and developing countries in a bid that such investments would add value to the country through economic growth, transfer of technology, capital accumulation and enhancement of human capital development, which may be achieved through education, trainings, and the transfer of management skills (Buckley, Clegg, \& Wang, 2002).

Increased interest in foreign direct investments in recent times could be attributed to the benefits associated with getting foreign investments. Pulatova (2016) attributed the increase in foreign direct investment to an increase in the volume of export, while other studies have also attributed the inflow of FDI to a transfer in information technology, as it gives the country a competitive edge as a result of new experience, knowledge, management style and production process (Melnyk, Kubatko, \& Pysarenko, 2014).

Countries are in constant competition to attract FDIs and the extent of investment depends on the tax policies such as corporate income tax reductions, tax holidays, accelerated depreciation, investment tax credits, and preferential treatment of income such as low taxes on earnings from exports (Kersan-Skabic \& Mirkovic, 2015). 


\section{Nigerian Tax System}

The Nigerian tax system comprises tax laws, tax policy and tax administration. Taxes are enforced by the three tiers of government comprising federal, state and local governments and as part of efforts to ensure an efficient tax system and orderly development of the Nigerian tax system, the national tax policy was introduced in 2012 with the most recent tax policy released in 2016. Several taxes are administered in Nigeria such as the companies' income tax, personal income tax, petroleum profits tax, education tax, value added tax, capital gains tax, national information technology development fund, custom and excise duties tax, amongst others. But for the sake of this study, our focus is on the following.

\section{Companies Income Tax}

The tax law guiding companies' income tax in Nigeria is the companies' income tax Act and it is administered exclusively by the Federal Inland Revenue Service (FIRS). Currently in Nigeria, the tax rate for Nigerian companies is $30 \%$ and is imposed on an entity who is covered under the definition of a company given by section 105 of the Act as "any company or corporation (other than corporation sole) established by or under any law in force in Nigeria or elsewhere". In a study carried out in Nigeria using data from 1996 to 2015, Akinwunmi et al. (2017) observed that there is a negative and insignificant relationship between companies' income tax and FDI in Nigeria.

In contrast, Saidu (2015) observed that there a negative and significant relationship between corporate tax rate and FDI in Nigeria, while also in a similar study by Eshghi and Eshghi (2016) they found that there is a significant negative relationship between corporate tax rate and FDI inflows in Central and Eastern European countries. Similarly, in study carried out in Romania, Nistor and Paun (2013) found a negative and significant relationship between companies' income tax and FDI suggesting that economic development attracts companies in their search for bigger markets and higher income.

\section{Petroleum Profit Tax}

The petroleum industry is the largest and main generator of GDP in Nigeria and accounts for over $90 \%$ of its total foreign earnings (Kwaji \& Dabari, 2017). Section 8 of the petroleum profits tax Act (PPTA) provides for the imposition of tax on the chargeable profit of companies that are engaged in petroleum operations in Nigeria.

\section{Value Added Tax}

In Nigeria, Value Added Tax (VAT) was introduced in 1994 and is centrally administered by the FIRS and hence, by decree 102 of 1993, VAT payers, manufacturers, wholesalers, and importers of taxable goods and services were required to register with the FIRS. The act however exempted some goods and services especially those that affect the welfare of people and are important in improving the welfare of people such as medical and pharmaceutical products, educational items amongst others.

In a study carried out in Nigeria, Akinwunmi et al. (2017) found that there is a positive and significant relationship between VAT and FDI in Nigeria and in contrast, Nistor and Paun (2013) found that there is a negative and significant relationship between value added tax and FDI.

\section{Education Tax}

The education tax was introduced in 1993 to fund the deteriorating education system and it is imposed on all registered companies in Nigeria, which are liable to pay tax under the companies income tax and petroleum profits tax acts. The education tax act No 7 LFN 1993, rests the responsibility of administering this tax on the FIRS. Its is charged at a rate of $2 \%$ on assessable profit of companies but a company that has an adjusted loss is not liable to pay education tax in that particular year. However, a company that defaults in paying the education tax within 60 days of receiving the notice of assessment is liable to a fine of 5\% plus interest at a commercial rate for non-compliance. Akinwunmi et al. (2017) observed that there is a negative and insignificant relationship between education tax and FDI for the period examined in their study. 


\section{National Information Technology Development Fund Levy}

The National Information Technology Development Fund Levy (NITDEF) was established by the National information development agency (NITDA) Act, LFN 2007. The act stipulates that a levy of $1 \%$ is imposed on the profit before tax of all companies in Nigeria who are internet service providers, telecommunications providers, pension managers and pension related companies, banks and other financial institutions and insurance companies, with an annual turnover of 100 million naira.

\section{Customs and Excise Duties Tax}

Custom and excise duties refers to a tax imposed on the imports or export of goods in or out of a country in order to raise revenue and protect domestic companies from predatory competition for foreign competitors (Ibadin \& Oladipupo, 2015). This type of tax is charged either as a percentage of the value of import or a fixed amount on specific quantity (Fasoranti, 2013).

Akinwunmi et al. (2017) observed that there is a negative and significant relationship between customs and excise duties and FDI in Nigeria.

\section{Review of Empirical Studies}

The impact of taxes on FDI is an area that has captured the attention of researchers as to if taxes imposed in the host countries encourage foreign investors to invest in these countries. Akinwunmi et al. (2017) examined the effect of the multiplicity of taxes on foreign direct investment in the Nigerian tax environment. They examined the effect of taxes such as companies' income tax, education tax, value added tax, custom and excise duties and inflation on foreign direct investment for the period 1996 to 2015, using ex-post facto research design. Data gathered were analysed using multiple regression technique and they found that there is an inverse relationship between multiple taxes and Foreign Direct Investment (FDI) in Nigeria; which implies that the higher the taxes, the less the FDI inflows into the country. They however observed that, the presence of multiple taxes hinders investments from foreigners and therefore recommended that if Nigeria wants to secure a place as an economically viable nation in Africa, it must strive and achieve an internationally competitive tax system by eliminating all forms of multiple taxes in the country.

Peters and Kiabel (2015) investigated the influence of tax incentives in the decision of an investor to locate FDI in Nigeria. Using the static Error Correction Modelling (ECM) to determine the time series properties of tax incentives captured by annual tax revenue as a percentage of Gross Domestic Product (GDP) and FDI, their findings revealed that there was a negative and significant relationship between tax incentives and FDI, suggesting that an increase in tax incentives does not bring about a corresponding increase in FDI. Based on the findings, they recommended that dependence on tax incentives should be reduced and more attention be put on other incentives strategies such as stable economic reforms and stable political climate.

Saidu (2015) examined the relationship between corporate taxation and foreign direct investment in Nigeria from 1970-1980. Data were analysed using Descriptive Statistic, correlation and regression. The independent variable corporate taxation was measured using corporate tax rate (CTR) whilst dependent variable foreign direct investment was measured using FDI net inflow ( $\%$ of GDP). GDP, exchange rate and inflation rate were used as control variables. The result showed negative significant relationship between CTR and FDI whilst exchange rate and FDI indicated negative insignificant relationship. However, GDP was positively insignificantly related with FDI whilst inflation had positive significant relationship with FDI. Based on the findings, the study recommended that there is need for the government to lo reduce corporate tax rate in order to attract FDI into the country.

Eshghi and Eshghi (2016) examined the impact of corporate tax rate on foreign direct investment inflows from Germany into five Central and Eastern European countries from 2000 to 2012. Using the forward-looking or statutory tax rate to measure the tax burden, they found that corporate tax rate has a significant negative impact on FDI inflows in Central and Eastern European countries. Their finding is in contrast with findings from previous research where backward looking tax rates extracted from corporate 
balance sheets were used as a measure of tax burden and showed that corporate tax rate has no impact on FDI inflows.

\section{METHODOLOGY}

This study employed the correlational research design in conducting the research and analysing the collected data which were obtained mainly from secondary sources, particularly from the Central Bank of Nigeria (CBN) Statistical bulletins, Federal Inland Revenue Service (FIRS), and National Bureau of Statistics (NBS). The time series data covers a period of 34 years i.e. 1982-2015 and was used to estimate the specified models. This time period was adopted for this study because the year 2015 signifies a major time in the Nigerian economy as during this period, there was economic collapse as a result of a fall in crude oil price and output.

\section{Theoretical Framework and Model Specification}

The theory underpinning this study is the tax competition theory. The theory was proposed by Oats in 1972 and proposes that in order to encourage the inflow of valuable resources and reduce the outflow of production resources, governments deliberately reduce economic burdens. Therefore, Kiburi, Mirie, Okiro, and Ruigu (2017) suggests that the tax competition theory may be used to understand governments efforts to reduce economic burdens in order to bring in more foreign investments such as skilled and qualified human capital and financial investments into the country.

Consequently, this theory suggests that in ensuring that enough foreign direct investments are attracted to a country, the governments try to ensure that their tax policies in place in terms of the tax rates and the taxes collected from foreign investments are favourable enough to attract new and retain the existing foreign investments in the country. Leaning on the tax completion theory and adapting the model of Akinwunmi et al. (2017), we expect a functional relationship between taxes and FDI in the form;

$F D I t=f($ taxes $)$

Decomposing equation (i) into the different forms of taxation, we have the model expressed as an implicit function;

FDIt $=\mathrm{f}($ PPTt, NITDEFt, VATt, CITt, ETtCEXTt, INFRt, EXRt, OPNt)

where: FDI is Foreign Direct investment, PPT is the Petroleum Profits Tax, NITDEF is National Information Technology Development Fund, VAT is Value Added Tax, CIT is Companies Income Tax, ET is Education Tax, CEXT is Customs and Excise Duties Tax, INFR is Inflation, EXR is Exchange Rate, and OPN is Trade Openness, $\mu$ is Stochastic term and $t$ is time.

Equation (ii) is expressed in explicit form as;

$$
\begin{aligned}
& \text { FDIt }=\beta 0+\beta 1 L P P T t+\beta 2 L N I T D E F t+\beta 3 L V A T t+\beta 4 L C I T t+\beta 5 L E T t+\beta 6 L C E X T t+ \\
& \beta 7 I N F R t+\beta 8 E X R t+\beta 9 O P N t+\mu t
\end{aligned}
$$

$\mathrm{L}$ stands for natural logarithm, $\beta_{0}$ is the Intercept, $\beta_{1}, \beta_{2}, \beta_{3}, \beta_{4}, \beta_{5,}, \beta_{6}, \beta_{7}, \beta_{8}$, and $\beta_{9}$ are elasticity of the output of Petroleum Profits Tax, National Information Technology Development Fund, Value Added Tax, Companies Income Tax, Education Tax, Customs and Excise Duties Tax, Inflation, Exchange Rate, and Trade Openness respectively.

\section{Method of Data Analysis}

The method of data analysis used in estimating the data collected is the Autoregressive Distributed Lag (ARDL) bounce testing procedure developed by Pesaran, Shin, \& Smith (2001) which is used to examine long-run relationship between taxes and foreign direct investments as well as short run 
dynamics. The bound test was adopted because it does not require that the variables under study must be integrated of the same level unlike the Johansen Cointegration approach, it is suitable for small or infinite sample data unlike the conventional approach which requires a large sample size, and the long and short run parameters of the model can be estimated simultaneously.

To estimate equation (iii), the study used time series data from 1981 to 2015 due to availability of data for the variables. The econometrics package (E-Views 10) was used in the estimation process.

The ARDL model for equation (iii) is specified as:

$$
\begin{aligned}
& \Delta \mathrm{FDI}=\delta 0+\sum_{i=1}^{p} \delta 1 \Delta \mathrm{LPPT} \mathrm{t}-1+\sum_{i=0}^{p} \delta 2 \Delta \mathrm{LNITDEFt}-1+\sum_{i=0}^{p} \delta 3 \Delta \mathrm{LVATt}-1+ \\
& \sum_{i=0}^{p} \delta 4 \Delta \mathrm{LCITt}-1+\sum_{i=0}^{p} \delta 5 \Delta \mathrm{LETt}-1+\sum_{i=0}^{p} \delta 6 \Delta \mathrm{LCEXTt}-1+\sum_{i=0}^{p} \delta 7 \Delta \mathrm{INFRt}-1+ \\
& \sum_{i=0}^{p} \delta 8 \Delta \mathrm{EXRt}-1+\sum_{i=0}^{p} \delta 9 \Delta \mathrm{OPNt}-1+\beta 1 \mathrm{LPPTt}-1+\beta 2 \mathrm{LNITDEFt}-1+\beta 3 \mathrm{LVATt}-1+ \\
& \beta 4 \mathrm{LCITt}-1+\beta 5 \mathrm{LETt}-1+\beta 6 \mathrm{LCEXTt}-1+\beta 7 \mathrm{INFRt}-1+\beta 8 \mathrm{ERT}-1+\beta 9 \mathrm{OPNt}-1+\mu \mathrm{t}
\end{aligned}
$$

Once cointegration is established, the long run relationship is estimated using the conditional ARDL model specified as:

FDIt $=\delta 0+\beta 1$ LPPTt $-1+\beta 2$ LNITDEFt $-1+\beta$ LVATt $-1+\beta 4$ LCITt $-1+\beta 5$ LETt $-1+$

$\beta 6$ LCEXTt $-1+\beta$ IINFRt $-1+\beta$ 8EXRt $-1+\beta$ OOPNt $-1+\mu \mathrm{t}$

The short run dynamic relationship is estimated using the error correction model specified as:

$$
\begin{aligned}
& \Delta \mathrm{FDI}=\delta 0+\sum_{i=1}^{p} \delta 1 \Delta \mathrm{LPPT} \mathrm{t}-1+\sum_{i=0}^{p} \delta 2 \Delta \mathrm{LNITDEFt}-1+\sum_{i=0}^{p} \delta 3 \Delta \text { LVATt }-1+ \\
& \sum_{i=0}^{p} \delta 4 \Delta \mathrm{LCITt}-1+\sum_{i=0}^{p} \delta 5 \Delta \mathrm{LETt}-1+\sum_{i=0}^{p} \delta 6 \Delta \mathrm{LCEXTt}-1+\sum_{i=0}^{p} \delta 7 \Delta \mathrm{INFRt}-1+ \\
& \sum_{i=0}^{p} \delta 8 \Delta \mathrm{EXRt}-1+\sum_{i=0}^{p} \delta 9 \Delta \text { OPNt }-1+\alpha \mathrm{ecmt}-1+\mu \mathrm{t}
\end{aligned}
$$

where: $\boldsymbol{\delta}_{0}$ : Constant term,

$\mu_{\mathrm{t}}:$ White noise

$\boldsymbol{\delta}_{\boldsymbol{1}^{-}}-\boldsymbol{\delta}_{\mathbf{9}}$ : Short run elasticities (coefficients of the first-differenced explanatory variables)

$\boldsymbol{\beta}_{\mathbf{1}}-\boldsymbol{\beta}_{\mathbf{9}}$ : Long run elasticites (coefficients of the explanatory variables)

$\mathbf{e c m}_{\mathbf{t}-1:}$ : Error correction term lagged for one period

$\boldsymbol{\alpha}$ : Speed of adjustment

$\Delta:$ First difference operator

P: Lag length

An F-test of the joint significance of the coefficients of the lagged levels of the variables were used to test the hypothesis of no cointegration amongst the variables against the presence of cointegration amongst the variables. The null hypothesis of no cointegration between Petroleum Profits Tax, National Information Technology Development Fund, Value Added Tax, Companies Income Tax, Education Tax, Customs and Excise Duties Tax, Inflation, Exchange Rate, and Trade Openness is given as:

$$
\mathrm{H} 0: \delta 1=\delta 2=\delta 3=\delta 4=\delta 5=\delta 6=\delta 7=\delta 8=\delta 9
$$

The alternative hypothesis was given as

$$
\mathrm{H} 1: \delta 1 \neq \delta 2 \neq \delta 3 \neq \delta 4 \neq \delta 5 \neq \delta 6 \neq \delta 7 \neq \delta 8 \neq \delta 9
$$

The F-test has a nonstandard distribution irrespective of whether the variables are 1(0) or 1(1). Pesaran et al. (2001) put forward two sets of adjusted critical values that provide the lower and upper bounds used for inference. One set assumes that all variables are 1(0) and the other assumes that they are 
all 1(1). If the computed F-statistics falls above the upper bound critical value, then the null hypothesis of no cointegration is rejected. If it falls below the lower bound, then the null hypothesis cannot be rejected. Finally, if it falls between the lower and upper bound, then the result would be inconclusive. The optimal lag length for the specified ARDL model was determined based on the Akaike Information Criterion (AIC).

\section{Measurement of Variables}

TABLE 1

OPERATIONALISATION OF VARIABLES

\begin{tabular}{|c|c|c|c|c|}
\hline Variables & Description & Types & Measurement & Source \\
\hline FDI & \begin{tabular}{|l} 
Foreign \\
Direct Investment
\end{tabular} & Dependent & $\begin{array}{l}\text { Foreign direct investment net } \\
\text { inflow (\% of GDP) }\end{array}$ & $\begin{array}{l}\text { Akinwunmi et al. } \\
(2017)\end{array}$ \\
\hline PPT & Petroleum profit tax & Independent & $\begin{array}{l}\text { Natural Logarithm of Petroleum } \\
\text { Profit Tax from } 1982 \text { till } 2015\end{array}$ & - \\
\hline CIT & $\begin{array}{l}\text { Company income } \\
\operatorname{tax}\end{array}$ & Independent & $\begin{array}{l}\text { Natural Logarithm of Company } \\
\text { income tax from } 1982 \text { till } 2015\end{array}$ & $\begin{array}{l}\text { Akinwunmi et al. } \\
(2017)\end{array}$ \\
\hline VAT & Value added tax & Independent & $\begin{array}{l}\text { Natural Logarithm of value added } \\
\text { tax from } 1982 \text { till } 2015\end{array}$ & $\begin{array}{l}\text { Akinwunmi et al. } \\
(2017)\end{array}$ \\
\hline NITDEF & $\begin{array}{l}\text { National } \\
\text { Information } \\
\text { technology } \\
\text { development fund } \\
\text { levy }\end{array}$ & Independent & $\begin{array}{l}\text { Natural Logarithm of National } \\
\text { Information technology } \\
\text { development fund levy from } 1982 \\
\text { till } 2015\end{array}$ & - \\
\hline ET & Education tax & Independent & $\begin{array}{l}\text { Natural Logarithm of education } \\
\text { tax from } 1982 \text { till } 2015\end{array}$ & $\begin{array}{l}\text { Akinwunmi et al. } \\
(2017)\end{array}$ \\
\hline CEXT & $\begin{array}{l}\text { Custom and excise } \\
\text { duties tax }\end{array}$ & Independent & $\begin{array}{l}\text { Natural Logarithm of Custom and } \\
\text { excise duties tax from } 1982 \text { till } \\
2015\end{array}$ & $\begin{array}{l}\text { Akinwunmi et al. } \\
(2017)\end{array}$ \\
\hline INF & Inflation rate & Control & Inflation rate & $\begin{array}{l}\text { Akinwunmi et al. } \\
\text { (2017); Peters and } \\
\text { Kiabel (2015); } \\
\text { Saidu (2015) }\end{array}$ \\
\hline OPN & Economy openness & Control & Trade Openness & $\begin{array}{l}\text { Peters and Kiabel } \\
(2015)\end{array}$ \\
\hline EXR & Exchange Rate & Control & Exchange rate of the economy & $\begin{array}{l}\text { Peters and Kiabel } \\
(2015) ; \text { Saidu } \\
(2015)\end{array}$ \\
\hline
\end{tabular}

Source: Researcher's compilation from Central Bank of Nigeria (CBN) Statistical bulletins, Federal Inland Revenue Service (FIRS), and National Bureau of Statistics (NBS) (2018)

\section{RESULTS AND DISCUSSION}

A time series is said to be non-stationary if the mean and variance of the time series are dependent over time. On the other hand, a time series is stated as stationary if the mean and variance are constant over time. According to Gordon (1995), most econometric time series are non-stationary and only achieve 
stationarity at the first or second difference. Generally, unit root test involves the test of stationarity for variables used in regression analysis. The importance of stationarity of time series used in regression borders on the fact that a non-stationary time series generalization will lead to a spurious conclusion. This makes forecasting based on such time series to be of little practical value. Moreover, regression of a nonstationary time series on another non-stationary time series may produce a spurious result.

\section{Descriptive Statistics}

TABLE 2

DESCRIPTIVE STATISTICS

\begin{tabular}{|l|l|l|l|l|l|l|l|l|l|l|}
\hline & FDI & LPPT & LNITDEF & LVAT & LCIT & LET & LCEXT & INFR & EXR & OPN \\
\hline Mean & 3.10 & 5.21 & 0.88 & 3.35 & 4.44 & 2.72 & 4.49 & 20.20 & 7.36 & 31.33 \\
\hline Median & 2.65 & 5.05 & 0.00 & 4.62 & 4.59 & 3.83 & 4.78 & 12.45 & 5.73 & 34.68 \\
\hline Maximum & 10.83 & 6.65 & 3.99 & 5.90 & 5.83 & 5.44 & 5.68 & 72.80 & 19.32 & 58.92 \\
\hline Minimum & 0.66 & 3.57 & 0.00 & 0.00 & 2.74 & 0.00 & 0.00 & 4.70 & 0.06 & 7.36 \\
\hline Std. Dev. & 2.23 & 1.05 & 1.62 & 2.55 & 1.03 & 2.23 & 1.14 & 18.09 & 6.61 & 12.82 \\
\hline Skewness & 1.78 & -0.08 & 1.27 & -0.51 & -0.25 & -0.34 & -1.83 & 1.47 & 0.17 & -0.23 \\
\hline Kurtosis & 6.31 & 1.59 & 2.66 & 1.38 & 1.68 & 1.29 & 7.92 & 3.94 & 1.33 & 2.46 \\
\hline Jarque-Bera & 33.67 & 2.83 & 9.38 & 5.16 & 2.82 & 4.76 & 53.48 & 13.54 & 4.08 & 0.72 \\
\hline Probability & 0.00 & 0.24 & 0.00 & 0.07 & 0.24 & 0.09 & 0.00 & 0.00 & 0.12 & 0.69 \\
\hline Sum & 105.60 & 177.45 & 30.00 & 113.99 & 150.98 & 92.80 & 152.76 & 686.96 & 250.32 & 1065.44 \\
\hline $\begin{array}{l}\text { Sum Sq. } \\
\text { Dev. }\end{array}$ & 165.56 & 37.06 & 86.79 & 216.02 & 35.13 & 164.58 & 43.06 & 10806.54 & 1442.67 & 5427.21 \\
\hline Observations & 34 & 34 & 34 & 34 & 34 & 34 & 34 & 34 & 34 & 34 \\
\hline
\end{tabular}

Note: $F D I=$ Foreign Direct investment, PPT = the Petroleum Profits Tax, NITDEF =National Information Technology Development Fund, VAT =Value Added Tax, CIT = Companies Income Tax, ET = Education Tax, CEXT $=$ Customs and Excise Duties Tax, INFR =Inflation, EXR = Exchange Rate, and OPN=Trade Openness Source: Output from E-views 10

Table 2 reports the descriptive statistic of the variables considered in this study. The mean value of FDI, LPPT, LNITDEF, LVAT, LCIT, LET, LCEXT, were 3.10, 5.21, 0.88, 3.35, 4.44, 2.72, and 4.49 respectively. Of particular interest, the average of our dependent variable FDI net inflow (\% of GDP) into the country was 3.10 with the highest FDI inflow of 10.83 and the lowest of 0.66 . The standard deviation for FDI was 2.23 which suggest a disturbing trend which is likely to put the growth of the economy at risk. This finding is similar to that of Saidu (2015). Further, all the independent variables were negatively skewed except for LNITDEF that was positively skewed. The control variables INFR, EXR and OPN have mean values of $20.20,7.36$ and 31.33 respectively and they were positively skewed with the exception of OPN. In terms of Kurtosis, LPPT, LNITDEF, LVAT, LCIT, LET, EXR, and OPN were Platykurtic suggesting that the distribution of the values do not have any outliers except for FDI, LCEXT and INFR which appears to be leptokurtic. 


\section{Correlation Analysis}

TABLE 3

PEARSON CORRELATION RESULT

\begin{tabular}{|l|l|l|l|l|l|l|l|l|l|l|}
\hline & FDI & LPPT & LNITDEF & LVAT & LCIT & INFR & EXR1 & LET & OPN & LCEXT \\
\hline FDI & 1 & & & & & & & & & \\
\hline PPT & 0.07 & 1 & & & & & & & & \\
\hline NITDEF & -0.06 & 0.95 & 1 & & & & & & & \\
\hline VAT & -0.84 & 0.04 & 0.27 & 1 & & & & & & \\
\hline CIT & -0.76 & -0.11 & 0.09 & 0.94 & 1 & & & & & \\
\hline INFR & 0.82 & 0.07 & -0.15 & -0.93 & -0.85 & 1 & & & & \\
\hline EXR & -0.62 & -0.49 & -0.22 & 0.76 & 0.74 & -0.78 & 1 & & & \\
\hline ET & -0.00 & 0.94 & 0.96 & 0.22 & 0.10 & -0.04 & -0.31 & 1 & & \\
\hline OPN & 0.36 & 0.50 & 0.28 & -0.59 & -0.73 & 0.55 & -0.78 & 0.26 & 1 & \\
\hline CEXT & -0.03 & -0.23 & -0.22 & 0.01 & 0.18 & 0.16 & 0.07 & -0.07 & -0.54 & 1 \\
\hline
\end{tabular}

For variable definition see Table 1

Source: Researchers' compilation from Eviews 10 (2018)

The Pearson correlation Table above shows the correlations between the variables. Focusing on the tax variables, it is observed that PPT is positively but weakly correlated with FDI( $\mathrm{r}=0.079)$, NITDEF shows negative and weak correlation with FDI $(\mathrm{r}=-0.0628)$, VAT and CIT displays strong correlation with FDI though with a negative coefficients $(\mathrm{r}=-0.8464, \mathrm{r}=-0.7681)$. The correlation between ET and FDI is negative and weak $(\mathrm{r}=-0.0038)$ and that between FDI and CEXT behaves similarly $(\mathrm{r}=-0-333)$. The control variables included reveals that INFR and OPN are positively correlated with FDI with coefficients of 0.829 and 0.361 respectively while EXR is negatively weakly correlated $(\mathrm{r}=-0.0038)$.

\section{Unit root Results}

The Augmented Dickey Fuller (ADF) test was employed in order to test for unit roots in this study. The results were presented in levels and first difference. It enabled us to determine in comparative terms the unit root among the time series and also to obtain more robust results. 
TABLE 4

UNIT ROOT TEST RESULTS

\begin{tabular}{|c|c|c|c|}
\hline \multicolumn{4}{|c|}{ Unit root test at levels } \\
\hline Variable & ADF-Test Statistic & 95\% Critical ADF Value & Remark \\
\hline FDI & -3.58 & -2.96 & Stationary \\
\hline PPT & -1.38 & -2.96 & Non-statioanry \\
\hline NITDEF & 0.38 & -2.96 & '9 \\
\hline VAT & -0.99 & -2.96 & 6 \\
\hline CIT & -1.45 & -2.96 & “' \\
\hline ET & -1.12 & -2.96 & “' \\
\hline CEXT & -2.35 & -2.96 & , \\
\hline INFR & -2.45 & -2.96 & ' \\
\hline OPN & -2.93 & -2.96 & 6 \\
\hline EXR & -0.96 & -2.96 & "9 \\
\hline \multicolumn{4}{|c|}{ Unit root test at $1^{\text {st }}$ difference } \\
\hline Variable & ADF-Test Statistic & 95\% Critical ADF Value & Remark \\
\hline FDI & -7.89 & -2.96 & Stationary \\
\hline PPT & -4.01 & -2.96 & " \\
\hline NITDEF & 4.88 & -2.96 & “' \\
\hline VAT & -5.14 & -2.96 & " \\
\hline CIT & -5.16 & -2.96 & 6 \\
\hline ET & -5.54 & -2.96 & 6, \\
\hline CEXT & -3.25 & -2.96 & \\
\hline INFR & -5.45 & -2.96 & 6 \\
\hline OPN & -7.60 & -2.96 & ' \\
\hline EXR & -7.47 & -2.96 & ' \\
\hline
\end{tabular}

For variable definition see Table 1

Source: Researchers compilation (2018).

The result indicates that all of the variables at levels except for FDI have ADF values that are less than the $95 \%$ critical ADF value of 2.96 . The implication of this is that the time series for these variables are non-stationary in their levels. Further, we take the first differences of the respective variables and perform the unit root test on each of the resultant time series. The rationale behind this procedure is that Box and Jenkins (1976) have argued that differencing non-stationary time series will make it attain stationarity. The result of the unit root test on these variables in first differencing shows that the ADF values in absolute terms is greater than the $95 \%$ critical ADF values. With these result, these variables are adjudged to be stationary. Thus we accept the hypothesis that the variables possess unit roots. Indeed the variables are integrated of order one i.e. I(1).

\section{Bounds Test for Dynamic Co-integration}

In terms of the effects of tax revenue on foreign direct investment in Nigeria, the study proposed the test of a long term autoregressive pattern of relationship. The first analysis, therefore, was to examine whether a long run relationship existed between FDI and the tax variables. Table 5 showed the result of the Bounds test of long run effects for the ARDL specifications for the equations. The evaluation of the results was based on the critical F-statistic values for the lower and upper bounds as also reported in the results. 
TABLE 5

BOUNDS TEST RESULTS

\begin{tabular}{llll}
\hline Equation & Tests & & \\
\hline \multirow{3}{*}{ FDI } & F-statistic & 8.40 & 7 \\
& Significance & I0 Bound & I1 Bound \\
& $5 \%$ & 2.32 & 3.5 \\
\hline & $1 \%$ & 2.96 & 4.26 \\
\hline
\end{tabular}

For variable definition see Table 1

Source: Researcher's Compilation from E-views 10 (2018).

According to the empirical output of the F-values in Table 5, it could be seen that the null hypothesis of no long-run relationship in the case of unrestricted regressions of the tax variables on FDI was rejected at the $5 \%$ level of significance. The results revealed that tax variables had strong long run relationship with the FDI.

\section{Autoregressive Distributed Lag (ARDL) Regression Result}

With the diagnostic and robustness tests concluded, we then proceeded to the estimation of the ARDL equation. It is important to mention that the Bounds test for long run relationship showed that the selected determinant factors actually moved together with FDI overtime in the study. That is the premise for the estimation of the dynamic ARDL models. The optimum lag length for the model was selected based on the Shwarz-Bayesian Information criterion (SIC). The results of the estimates are presented below.

TABLE 6

SHORT-RUN ARDL RESULT

\begin{tabular}{l|llll}
\hline Variable & Coefficient & Std. Error & t-Statistic & Prob. \\
\hline C & -15.84 & 2.24 & -7.04 & $0.00^{* * *}$ \\
D(LPPT) & 5.60 & 1.45 & 3.85 & $0.00^{* * *}$ \\
D(LPPT(-1)) & -2.17 & 1.28 & -1.69 & 0.12 \\
D(LNITDEF) & -0.98 & 0.38 & -2.54 & $0.03^{* *}$ \\
D(LNITDEF(-1)) & 2.18 & 0.47 & 4.61 & $0.00^{* * *}$ \\
D(LVAT) & 0.37 & 0.41 & 0.90 & 0.39 \\
D(LVAT(-1)) & 5.95 & 1.87 & 3.18 & $0.01 * *$ \\
D(LCIT) & 0.75 & 4.33 & 0.17 & 0.86 \\
D(LCIT(-1)) & 8.49 & 4.38 & 1.93 & $0.08^{*}$ \\
D(LET) & -7.26 & 1.76 & -4.10 & $0.00^{* * *}$ \\
D(LET(-1)) & -2.25 & 0.59 & -3.81 & $0.00^{* * *}$ \\
D(LCEXT) & -0.76 & 0.19 & -3.83 & $0.00^{* * *}$ \\
D(LCEXT(-1)) & 0.44 & 0.18 & 2.37 & $0.04 * *$ \\
INFR & 0.08 & 0.01 & 5.13 & $0.00^{* * *}$ \\
EXR & -0.06 & 0.01 & -5.85 & $0.00^{* * *}$ \\
OPN & -0.05 & 0.03 & -1.82 & 0.10 \\
ECM(-1) & -0.98 & 0.14 & -6.61 & $0.00^{* * *}$ \\
\hline
\end{tabular}




\begin{tabular}{l|lll}
\hline & \multicolumn{3}{|c}{ Model Fit } \\
\hline R-squared & 0.89 & Mean dependent var & -2.78 \\
Adjusted R-squared & 0.78 & S.D. dependent var & 2.45 \\
S.E. of regression & 1.13 & Akaike info criterion & 3.39 \\
Sum squared resid & 19.21 & Schwarz criterion & 4.16 \\
Log likelihood & -37.24 & Hannan-Quinn criter. & 3.64 \\
F-statistic & 8.19 & Durbin-Watson stat & 2.35 \\
Prob(F-statistic) & 0.00 & & \\
\hline
\end{tabular}

For variable definition see Table 1

$*$ significance at the .10 level, ** significance at the .05 level, ***significance at the .01 level.

Source: Researchers compilation (2018).

Table 6 presents the results of the short run behaviour of FDI. The model possessed an impressive goodness of fit with adjusted $\mathrm{R}^{2}$ value at 0.78 which implies that over $78 \%$ of the proportional changes in FDI were explained by the independent variables. The F-value of 8.19 also showed that the joint movement among the explanatory variables on FDI was significant even at the $1 \%$ level. It showed that the determinant factors all combined to exert significant effects on FDI in Nigeria. A close look at the individual coefficients of the explanatory variables revealed that the PPT has a positive and significant effect FDI both the current levels at (5.60) but negative though not significant at the first lag at (-2.17). The results showed that NITDEF also had a significant impact on short run movements in FDI in Nigeria, positive at levels $(-0.98)$ but negative at first lag (2.18). The short run behaviour of FDI to VAT shows positive and significant response to VAT at first lag (5.95) while positive (0.37) at levels though not significant.CIT is not significant at $5 \%$ both in levels and first lag though with positive coefficients of 0.75 and 8.49 respectively. The short run effect of ET on FDI is negative. The results showed that CEXT also had a significant impact on short run movements in FDI Nigeria, negative at levels $(-0.76)$ but positive at first lag (0.44). The coefficient of the co-integrating equation (ECM-1) had the expected negative sign and was significant at the $1 \%$ level. The ECM term is very high at 0.98 and significant at $5 \%$ and thus confirms that about $98 \%$ of short run fluctuations will be corrected within one year.

The long run ADRL result is presented in Table 7 below and as observed, NTDEF has a negative ($0.56)$ and significant $(\mathrm{P}=0.03)$ impact on FDI and this implies that a drop in the NTDEF will stimulate FDI flows into the country. VAT also a positive $(0.94)$ and significant $(\mathrm{p}=0.01)$ effect on FDI and as such a raise in the VAT rate will not distort FDI flows but will actually improve it. VAT burden is on consumers and not on producers and hence its effect on FDI may be indirect going through demand behaviour of the market occasioned by a mark-up from VAT. 
TABLE 7

LONG RUN ARDL RESULTS

\begin{tabular}{|c|c|c|}
\hline Variable & $\begin{array}{l}\text { Aprori } \\
\text { Sign }\end{array}$ & $\begin{array}{l}\text { Beta, } \\
\text { \{ \} standard error } \\
\text { ( ) p-values }\end{array}$ \\
\hline $\mathrm{C}$ & & $\begin{array}{l}-11.68 * * * \\
3.72 \\
(0.00)\end{array}$ \\
\hline PPT & & $\begin{array}{l}-0.95 \\
1.27 \\
(0.46)\end{array}$ \\
\hline NITDEF & & $\begin{array}{l}-0.56^{* *} \\
0.22 \\
(0.02)\end{array}$ \\
\hline VAT & & $\begin{array}{l}0.94 * * * \\
0.33 \\
(0.01)\end{array}$ \\
\hline CIT & & $\begin{array}{l}5.54 * * * \\
1.88 \\
(0.00)\end{array}$ \\
\hline ET & & $\begin{array}{l}-1.92 * * * \\
0.40 \\
(0.00)\end{array}$ \\
\hline CEXT & & $\begin{array}{l}-0.15 \\
0.20 \\
(0.45)\end{array}$ \\
\hline Model diagnostics & & \\
\hline $\begin{array}{l}\text { Breusch-Godfrey Serial Correlation LM } \\
\text { Test }\end{array}$ & & 0.25 \\
\hline Heteroskedasticity Test: B-P-G & & 0.54 \\
\hline Ramsey Reset Test F-Stat & & 0.26 \\
\hline Normality Test & & 0.00 \\
\hline
\end{tabular}

For variable definition see Table 1

* significance at the .10 level, ** significance at the .05 level, ***significance at the .01 level.

Note: The coefficient and t-values are presented with the probability values in parenthesis.

Source: Researchers compilation (2018).

Table 7 presents the results of the long run behaviour of FDI. From the model, the Breusch-paganGodfrey Lagrange Multiplier (LM) test for heteroskedasticity and the Ramsey RESET test showed high probability values that were greater than 0.05 and hence satisfies all necessary checks. CIT has a positive (5.54) and significant $(\mathrm{P}=0.00)$ impact on FDI and this implies that a raise in CIT will not distort FDI flows into the country. This finding is contrary to the findings of prior studies (Akinwunmi et al., 2017; Eshghi \& Eshghi, 2016; Nistor \& Paun, 2013; Saidu, 2015). On the contrary, ET showed a negative (-1.92) and significant $(\mathrm{p}=0.00)$ effect on FDI and by implication, a drop in the ET will stimulate FDI flows. This finding is contrary to the finding of Akinwunmi et al. (2017). While NITDEF showed a negative (-0.56) and significant $(\mathrm{p}=0.02)$ effect on FDI suggesting that an increase in NITDEF will reduce FDI flows. Further, VAT was positive (0.94) and significant (0.01), suggesting that an increase in VAT will not distort FDI flows into the country. This finding is in tandem with Akinwunmi et al. (2017) and at variance with Nistor \& Paun (2013). CEXT has a negative effect on FDI flows suggesting that increasing the CEXT rate will distort the flow of FDI downwards. However, the effect is non-significant in the ARDL estimates. This finding is at contrast with the finding of Akinwunmi et al. (2017). The regression estimates also showed that there is an insignificant relationship between PPT and FDI. 


\section{CONCLUSION AND RECOMMENDATIONS}

The study examined the effect of taxes on foreign direct investment in Nigeria for a period of 34 years from 1982 to 2015. The estimates indicate that taxes such as national information development fund, and education tax has a negative and significant relationship with foreign direct investment and that there exists a positive and significant relationship between value added tax, companies' income tax and foreign direct investments.

Based on these findings, the study recommends that there is need for the government to come up with more friendly economic policies and macroeconomic adjustments that will lead to continuous increase and growth of the nation's GDP and stable inflation rate thereby paving way for a friendly business environment, judiciously use revenue generated from tax to provide the basic infrastructures like pipe borne water, electricity, good roads and enhanced communications networks that is relatively cheap so as to attract investors, ensure that taxes imposed by tax authority are determined by the consideration of direct effect on investments, efficiency and fairness, and continue to monitor the economic effect of specific taxes on the taxpayer with a view of constantly updating and improving the existing tax laws in conformity with international acceptable standard.

\section{REFERENCES}

Akinwunmi, A. J., Olotu, A. E., \& Adegbie, F. F. (2017). Multiplicity of taxes and foreign direct investment: A relational analysis of Nigerian environment. Social Sciences, 6(4), 91 - 101.

Becker, J., Fuest, C., \& Hemmelgarn, T. (2006). Corporate tax reform and foreign direct investment in Germany - Evidence from firm-level data. Cesifo Working Paper Series, No. 1722. Retrieved from ssrn: https://ssrn.com/abstract $=905754$

Buckley, P. J., Clegg, J., \& Wang, C. (2002). The impact of inward FDI on the performance of Chinese manufacturing firms. Journal of International Business Studies, 33(4) 637 - 655.

Box, G.E.P., \& Jenkins, G.M. (1976). Time series analysis, forecasting and control. Holden-Day: San Francisco.

Eshghi, G., \& Eshghi, A. (2016). Corporate income tax as a determinant of foreign direct investment in central and eastern Europe. European Journal of Business and Social Sciences, 4(11), 111 - 123.

Fasoranti, M.M. (2013). Tax productivity and economic growth. Lorem Journal of Business and Economics, 1(1), 1-10.

Gordon, D. V. (1995). Optimal lag length in estimating dickey-fuller statistics: An empirical note. Applied Economics Letters, 2(6), 188 - 190.

Gondor, M., \& Nistor, P. (2012). How does FDI react to fiscal policy? The case of Romania. Procedia Economics and Finance, 3(1), $629-634$.

Ibadin, P. O., \& Oladipupo, A. O. (2015). Indirect taxes and economic growth in Nigeria. Ekon. Misao I Praksa Dbk, 24(2), 345-364.

John, E. I. (2016). Effect of foreign direct investment on economic growth in Nigeria. European Business and Management, 2(2), $40-46$.

Kersan-Skabic, I., \& Mirkovic, M. (2015). The importance of corporate taxation for FDI attractiveness of southeast European countries, Panoeconomicus, 62(1), 105 - 122.

Kiburi, W. W., Mirie, M. W., Okiro, K. O., \& Ruigu, G. M. (2017). The relationship between tax burden and foreign direct investment inflows: A review of empirical literature. European Journal of Accounting, Auditing and Finance Research, 5(5), 67 - 77.

Kwaji, S. F., \& Dabari, I. J. (2017). Empirical analysis of tax revenue collection by the federal government in Nigeria. European Journal of Accounting, Auditing and Finance Research, 5(2), 1 -11 .

Melnyk, L., Kubatko, O., \& Pysarenko, S. (2014). The impact of foreign direct investment on economic growth: Case of communism transition economies. Problems and Perspectives in Management, $12(1), 17-24$. 
Morisset, J. (2003). Using Tax Incentives to Attract Foreign Direct Investment. Retrieved from http://www.rru.worldbank.org.documents.

National information technology development agency Act 2007. (n.d.). www.nitda.gov.ng

Nistor, I., \& Paun, D. (2013). Taxation and its effects on foreign direct investments - The case of Romania. Nanki O Finansach Financial Sciences, 3(16), 37 - 47.

Okoi, W. W., \& Edame, E. (2013). The Impact of Taxation on Economic Development in Nigeria: A Case of Small Scale Businesses in Calabar Metropolis (1980-2010). Calabar: Department of Economics, Unpublished PGD Economics Thesis.

Organization for Economic Corporation and Development (OECD) (2002). Foreign direct investment for development: Maximizing benefits, minimizing costs, OECD Publications Service.

Peters, G. T., \& Kiabel, B. D. (2015). Tax incentives and foreign direct investment in Nigeria. IOSR Journal of Economics and Finance, 6(5), 10 - 20.

Pesaran, M., Shin, Y., \& Smith, R. (2001). Bounds testing approaches to the analysis of level of relationship. Journal of Applied economics, 16(1), 236 - 289.

Pulatova, M. (2016). Effects of foreign direct investment and firm export in economic growth: Evidence from Uzbekistan. European Journal of Business and Management, 8(3), 179 - 182.

Raian, J. R. (2004). Measures to attract FDI: Investment promotion, incentives and policy intervention. Economic and Political Weekly, 1(1), 12-16.

Saidu, A. S. (2015). Corporate taxation and foreign direct investment in Nigeria. European Journal of Accounting, Auditing and Finance Research, 3(8), 17 - 24.

UNCTAD (2007). World Investment Report 2007: Transnational Corporations, Extractive Industries and Development. Retrieved from http://unctad.org/en/Docs/wir2007p4_en.pdf 